\title{
Postgraduate education of hospital directors
}

\author{
Marcin Kautsch ${ }^{1}$ (1) https://orcid.org/0000-0002-4520-3560 \\ Roksana Dela ${ }^{2}$ (1) https://orid.org/0000-0002-3831-4158
}

Ilona Barańska ${ }^{3}$ (1) https://orcid.org/0000-0001-5709-099x

\begin{abstract}
${ }^{1}$ Zakład Polityki Zdrowotnej i Zarządzania, Instytut Zdrowia Publicznego, Wydział Nauk o Zdrowiu, Uniwersytet Jagielloński Collegium Medicum

${ }^{2}$ Doktorantka w Instytucie Zdrowia Publicznego, Wydział Nauk o Zdrowiu, Uniwersytet Jagielloński Collegium Medicum

${ }^{3}$ Zakład Socjologii Medycyny, Katedra Epidemiologii i Medycyny Zapobiegawczej, Wydział Lekarski, Uniwersytet Jagielloński Collegium Medicum
\end{abstract}

Address for correspondence: Marcin Kautsch, Instytut Zdrowia Publicznego, 31-531 Kraków, Grzegórzecka 20, marcin.kautsch@uj.edu.pl

\section{Abstract}

The reforms of the healthcare system (market economy of the sector) have changed the requirements for Poland's hospital directors. Consequently, ever greater numbers of non-doctors have been appointed to these positions in recent years. One of the responses to this change in the requirements has been directors undertaking postgraduate studies in order to enhance their qualifications or by others to meet the requirements included in recruitment competitions to select a director. The research conducted in 2017 on a group of 137 directors found out that the majority of respondents completed at least one postgraduate course of study. The groups more often undertaking a course of study, or more than one course comprised women, non-doctors, especially those with an engineering education, and younger people. The studies most often chosen were in the field of healthcare management, which comprised $43 \%$ of all studies undertaken by the research group. Those least interested in postgraduate studies were doctors.

\section{Key words: hospital directors, postgraduate education, Poland \\ Slowa kluczowe: dyrektorzy szpitali, ksztaicenie podyplomowe, Polska}

\section{Introduction}

To adequately perform in any profession requires the appropriate competencies. The term competence is variously defined in the literature on the subject:

- a collection of managerial, technical and expert knowledge [1];

- qualifications, covering all permanent human properties, forming a relationship with the high effects achieved by the employee, having a universal dimension [2];

- an alliance of skills, knowledge, experience and commitment by employees [3];
- knowledge, abilities, activity styles, personality traits, interests and many other factors and traits [4].

Dictionary definitions list knowledge, skills and experience [5], or knowledge and skills [6] as component elements; they refer to competences as the ability to perform certain activities on the basis of knowledge and experience [7]. It is evident that knowledge is the element appearing in all definitions, although knowledge alone is not enough to say that a person is competent.

The dynamic nature of the market means that the scope of competencies required to work in a given position may change. These changes may also mean that in a given sector there are people who have previously 
worked in a completely different sector, exemplified by the healthcare system. For many years in Poland, it was principally doctors who were the directors of hospitals. Since the 1990s market economy forces have meant that the healthcare system has undergone major changes. Since the implementation of the universal health insurance system [8], private enterprises have joined the race for public funds and their growing potential started to put pressure on the public facilities. Until the introduction of the hospital network [9], the public health authority's option of signing a contract for health services was less and less determined by whether the providing facility was public or non-public. Provided the relevant requirements were met, according to the decisions of the President of the National Health Fund regarding the conditions for concluding and implementing contracts, the signing of the contract was not conditioned by the legal status of the healthcare entity. This is still the case for non-hospital services. The changes in the sector should also include the increasingly dramatic situation on the labour market - the rapid ageing of medical staff, especially nurses [10], which is making management in the healthcare system increasingly difficult.

In addition, with the growing expectations and demands of patients [11], it can be concluded that new conditions have emerged which require managers of healthcare facilities to have increasingly higher levels of management competence.

\section{The aim of the study}

The purpose of the study was to determine whether, and to what extent, hospital directors in Poland undertake postgraduate studies which may be helpful to them in managing subordinate units. The above purpose was achieved by studying the postgraduate education undertaken by those employed as hospital directors.

\section{Methodology}

This paper is based on a literature review and a survey conducted in 2017.

The review included an analysis of the legal acts and the existing data available on the internet identified by the Google search engine. The analysis was based on the first 10 pages of results. The databases of PubMed, Google Scholar and the Polish Medical Library were also reviewed. The search used a combination of the words "director", "manager", "hospital", "healthcare", "hospital director profile", "education", "postgraduate studies" in Polish and English. The keywords and their combinations describing the profile of the hospital director were established before conducting the 2017 study, while those related to the education of directors were carried out in 2019. The survey was conducted using a questionnaire, consisting of closed and open questions. The questions posed related to gender, age, work experience in the healthcare sector and for the position of hospital director, completed degree studies and postgraduate studies.
As there has been a significant increase in the number of units classified as hospital in recent years, it was decided to pre-select organisations that can be regarded as hospitals. The systemic changes resulted in categorising units with beds as hospitals, even if the number of beds was minimal, only a few. By using this approach, it was found that 957 units were considered to be hospitals in 2016 [12]. After analysing the data in the Register of Medical Entities maintained by the Centre of Healthcare Information Systems, those which did not have at least 50 beds were excluded from the study. Consequently, at the time of the study there were 611 units in Poland meeting the above criterion.

The questionnaire was sent electronically to the email address of these hospitals as given in the above register, together with a letter explaining the purpose of the study. If the message did not reach the addressee, the questionnaire was sent to the address available on the website of the facility. The questionnaire was sent to the units four times. Responses with data were received from 137 units, i.e. $22 \%$ of the units. The data were then subjected to a statistical analysis.

The average and standard deviation $(S D)$ were used to describe the sample or the median and interquartile range $(I Q R)$ for the quantitative variables. The compliance of the distributions with the normal distribution was checked by the Shapiro-Wilk test. The multivariate analysis was used for the qualitative variables. The qualitative variables with a few categories were coded in such a way that the minimum number of observations in each category was equal to or greater than 10 . The quantitative variables were transformed using median values. A one-way relationship between the number of completed postgraduate studies, the completion of studies in the field of "Healthcare Management" and selected variables (age, sex, education, length of employment in the healthcare sector, length of employment as a hospital director, hospital status and the establishing authority) was tested by the chi square test (qualitative variables), Student's t test for independent samples, Anova (quantitative variables with a distribution according to the normal distribution) or the MannWhitney $U$ test and Kruskal-Wallis test (quantitative variables with a distribution not compatible with the normal distribution). To evaluate the multifactorial relationship, two analyses were used: (1) linear regression (the number of completed postgraduate studies), giving the value of the non-standardised regression coefficient $(B), 95 \%$ confidence interval for $B(95 \% \mathrm{CI})$ and the value of the level of statistical significance $(p)$; (2) logistic regression (completion of post-graduate studies in healthcare management, giving an odds ratio (OR), 95\% CI for OR and $p$. To assess the goodness of the fit of the linear regression model, the analysis of the normality of the distribution of standardised residues was used. The assumed statistical confidence level $(\alpha)$ is 0.05 . The analyses were performed with the use of the SPSS 25 statistical package. 


\section{Postgraduate studies}

The systemic changes that occurred in Poland led to a rapid development of postgraduate education, which, to some extent, can be attributed to market changes that need large numbers of people to obtain new competencies and the universities need to search for new sources of income. Consequently, many universities have for several years been offering postgraduate studies to various groups of people so that there is a broad spectrum of studies $^{1}$ available to those interested. Of course, competencies can be, and are, raised by participating in various other types of training courses or other programmes, however, the inability to measure and compare these forms of training resulted in them being excluded from the study described in this paper. Therefore, reference was made to what Bakonyi, by referring to the provisions of the Act - Law on Higher Education [13], defined as studies when they involve a statutory number of hours and conclude with the defence of a thesis [14]. The number of postgraduate students in Poland is given in Table I. The decrease in the number of students in the last period presented, probably, can be attributed to the demographic changes occurring in Poland which are reducing the number of people of working age who wish to take up these studies.

\begin{tabular}{|c|c|c|c|c|}
\hline Year & $\mathbf{1 9 9 0}$ & $\mathbf{2 0 0 0}$ & $\mathbf{2 0 1 0}$ & $\mathbf{2 0 1 6}$ \\
\hline Number of students & 26,140 & 146,750 & 185,418 & 157,984 \\
\hline Percentage change & - & $461 \%$ & $26 \%$ & $-15 \%$ \\
\hline
\end{tabular}

Table I. Postgraduate students.

Source: Own study based on: Central Statistical Office, The Statistical Yearbook of the Republic of Poland 2017, Warsaw 2018: 361 [15]; Central Statistical Office, The Statistical Yearbook of the Republic of Poland 2001, Warsaw 2002: 254 [16].

A similar situation occurred in the healthcare sector with the strong development of a large number of studies being offered. Taking into account the subject of this paper one can indicate the emerging offers of courses on healthcare management; management as such, economics/health economics /health services; etc. The range of such topics is dictated by the systemic changes, before which hospitals were managed by doctors. The majority of these doctors did not have any management education. Their competencies stemmed from experience, not "formal" knowledge acquired during MA or postgraduate studies.

The change in the basic master's level of education of directors [17] as well as the stronger market forces in the sector may have induced at least two trends in relation to postgraduate studies. Non-medical directors may have needed to improve their knowledge and qualifications in the healthcare system/management. Meanwhile doctors, like their non-medical colleagues, needed enhancement in the general areas of management or more sector-oriented management, which is healthcare management. These factors raised the interest in studies in the field of healthcare management, as confirmed by the results of the research presented below.

\section{Postgraduate education of hospital directors}

The results of the literature review proved to be extremely modest. Searches of the scientific databases did not bring any significant results. Except for the three articles [17-19], none contained information that specifically related to the postgraduate education of hospital directors.

The analysis, described in the methodology, of the data derived from Internet sources did not yield results useful for further research. The search revealed advertisements about studies, information about changes in the positions of hospital directors with notes about education (degree and postgraduate) and announcements of competitive applications for positions as hospital directors. These announcements often included the requirement that the candidate should have relevant experience (usually 5, but less often 6 years of work in a managerial position) or some experience ( 3 years of work in a managerial position) and had completed postgraduate studies in management. However, these requirements result directly from the statutory provisions (Act on Medical Activity, Art. 46.2 [20]) describing the requirements of persons applying for the position of hospital director.

\section{Resullts}

The results of the study are given in the tables below and are then discussed. The choice of categories in which this was undertaken depended on the size of the group. The groups in which there were more than 10 were selected for the analysis, the remaining groups were placed in the 'others' category.

\section{Characteristics of the researched sample}

The average age of the respondents was 54.3 years ( $\pm S D$ 7.9), with men being about 3 years older than women. There were no major differences between men and women in the distribution of their length of employment in healthcare or in the director's position (Table II).

For the analysis of the age of directors, five-year age ranges were created. At the same time, because of the different retirement ages of women and men and the small numbers in some age groups, the categories shown in Table III, giving more detailed data on the differences between women and men, were adopted for the analyses.

The age distribution in the groups of men and women was slightly different. In the case of women, the distribution was rather even, however, for men, $42 \%$ were in the 56-65 age range.

The data presented in Table III clearly show that almost $2 / 3$ of people currently employed as hospital directors have a non-medical educational background. This is 


\begin{tabular}{|c|c|c|c|c|c|c|c|}
\hline & \multicolumn{2}{|r|}{ Total } & \multicolumn{2}{|r|}{ Men } & \multicolumn{2}{|r|}{ Women } & \multirow{2}{*}{$p^{*}$} \\
\hline & $n$ & Average (SD) & $n$ & Average (SD) & $n$ & Average $(S D)$ & \\
\hline Age [years] & 137 & $54.3(7.9)$ & 88 & $55.3(8)$ & 49 & $52.6(7.5)$ & 0.053 \\
\hline Length of employment in healthcare [years] & 137 & $20.9(11.6)$ & 88 & $20.5(11.9)$ & 49 & $21.6(11.2)$ & 0.589 \\
\hline Length of employment as hospital director [years] & 137 & $8.2(7.3)$ & 88 & $8.6(8.2)$ & 49 & $7.5(5.1)$ & 0.829 \\
\hline
\end{tabular}

* p for t tests for independent samples, or the Mann-Whitney U test

Table II. Characteristics of the studied group related to gender $(n=137)$.

Source: Own study.

\begin{tabular}{|c|c|c|c|c|c|c|c|}
\hline & \multicolumn{2}{|c|}{ Total } & \multicolumn{2}{|c|}{ Men } & \multicolumn{2}{|c|}{ Women } & \multirow{2}{*}{$p^{*}$} \\
\hline & $n$ & $\%$ & $n$ & $\%$ & $n$ & $\%$ & \\
\hline \multicolumn{8}{|l|}{ Age } \\
\hline Less than 45 years & 20 & 14.6 & 10 & 11.4 & 10 & 20.4 & \multirow{5}{*}{0.014} \\
\hline $45-50$ years & 26 & 19.0 & 15 & 17.0 & 11 & 22.4 & \\
\hline $51-55$ years & 29 & 21.2 & 19 & 21.6 & 10 & 20.4 & \\
\hline $56-60$ years women and $56-65$ men & 45 & 32.8 & 37 & 42.0 & 8 & 16.3 & \\
\hline over 61women and over 66 men & 17 & 12.4 & 7 & 8.0 & 10 & 20.4 & \\
\hline \multicolumn{8}{|l|}{ Education } \\
\hline Economic & 26 & 19.0 & 11 & 12.5 & 15 & 30.6 & \multirow{5}{*}{0.004} \\
\hline Engineering & 18 & 13.1 & 16 & 18.2 & 2 & 4.1 & \\
\hline Medical & 46 & 33.6 & 35 & 39.8 & 11 & 22.4 & \\
\hline Legal & 17 & 12.4 & 11 & 12.5 & 6 & 12.2 & \\
\hline Other & 30 & 21.9 & 15 & 17.0 & 15 & 30.6 & \\
\hline \multicolumn{8}{|l|}{ Education (simplified) } \\
\hline Medical & 46 & 33.6 & 35 & 39.8 & 11 & 22.4 & \multirow{2}{*}{0.040} \\
\hline Non-medical & 91 & 66.4 & 53 & 60.2 & 38 & 77.6 & \\
\hline \multicolumn{8}{|l|}{ Hospital status } \\
\hline Non-public healthcare facility & 31 & 23.1 & 17 & 19.8 & 14 & 29.2 & \multirow{2}{*}{0.216} \\
\hline Independent state healthcare facility & 103 & 76.9 & 69 & 80.2 & 34 & 70.8 & \\
\hline \multicolumn{8}{|l|}{ Establishing authority } \\
\hline County $^{2}$ & 64 & 50.0 & 43 & 51.2 & 21 & 47.7 & \multirow{3}{*}{0.509} \\
\hline Province & 42 & 32.8 & 28 & 33.3 & 14 & 31.8 & \\
\hline $\begin{array}{l}\text { Ministry (Ministry of Health, Ministry } \\
\text { of National Defence, Ministry of Internal } \\
\text { Affairs and Administration) }\end{array}$ & 11 & 8.6 & 8 & 9.5 & 3 & 6.8 & \\
\hline Others ${ }^{3}$ & 11 & 8.6 & 5 & 6.0 & 6 & 13.6 & \\
\hline
\end{tabular}

* p for chi $i^{2}$ tests or for Fisher's exact test

Lack of data: establishing authority $=9$, hospital status $=3$.

Table III. Differences in the range of chosen quality variables for women and men $(n=137)$.

Source: Own study.

a significant change compared to the situation at the start of the changes to the system, when the directors were exclusively doctors. The analysis of the data about the hospitals in which the surveyed directors worked revealed that it was most often a County $(50 \%)$ or a Province $(32.8 \%)$ as the entity that established the hospital. No statistically significant differences between men and women in this respect were found. 


\section{Relationship between education and gender and the number of postgraduate studies completed}

The data in Table IV indicate that on average each director completed more than one postgraduate study, with women completing more studies than men. It is also seen that non-doctors were more likely to improve their competencies by study than doctors. Persons with a legal education have completed the same number of studies as those with an economic education. People having an engineering education completed significantly more studies, the highest of those in the researched groups, followed by people having been educated in other fields of study.

\begin{tabular}{|c|c|c|c|c|}
\hline \multirow[b]{2}{*}{ Gender } & \multicolumn{4}{|c|}{ Number of completed studies } \\
\hline & $n$ & Average & $S D$ & $p^{*}$ \\
\hline Total & 137 & 1.18 & 1.01 & \multirow{3}{*}{0.012} \\
\hline Men & 88 & 1.02 & 1.01 & \\
\hline Women & 49 & 1.45 & 1.08 & \\
\hline \multicolumn{5}{|l|}{ Education } \\
\hline Economic & 26 & 1.23 & 0.99 & \multirow{5}{*}{$<0.001$} \\
\hline Engineering & 18 & 1.67 & 1.28 & \\
\hline Medical & 46 & 0.67 & 0.60 & \\
\hline Legal & 17 & 1.24 & 0.83 & \\
\hline Other & 30 & 1.57 & 1.30 & \\
\hline \multicolumn{5}{|l|}{ Education (simplified) } \\
\hline Medical & 46 & 0.67 & 0.60 & \multirow{2}{*}{$<0.001$} \\
\hline Non-medical (total) & 91 & 1.43 & 1.14 & \\
\hline
\end{tabular}

* p for Student's t-test for independent samples or Welch's test

Table IV. Relationship between education and gender and the number of completed postgraduate studies $(n=137)$.

Source: Own study.

\section{Distribution of the number of completed postgraduate studies in gender and education groups}

The analysis of the same data in qualitative terms indicates that women completed two or more postgraduate studies almost twice as often as men $40.8 \%$ and $22.7 \%$, respectively, $p=0.034$ (Table $\mathbf{V}$ ).

Almost $3 / 4$ of directors $(73 \%)$ claimed they had completed postgraduate studies. ${ }^{4}$ Additionally, 5 people stated they had enhanced their qualifications in a different way - by completing an MBA, other Master's degrees, doctoral studies or other specialisations. If this broader understanding of postgraduate education were adopted, the percentage of those who had completed postgraduate studies would be $77 \%$.

\begin{tabular}{|l|c|c|c|c|c|c|c|}
\hline \multirow{2}{*}{} & \multicolumn{2}{|c|}{ 0 } & \multicolumn{2}{c|}{$\mathbf{1}$} & \multicolumn{2}{c|}{ 2 or more } & \multirow{2}{*}{$*$} \\
\cline { 2 - 7 } & $\boldsymbol{n}$ & $\mathbf{\%}$ & $\boldsymbol{n}$ & $\mathbf{\%}$ & $\boldsymbol{n}$ & $\mathbf{\%}$ & \\
\hline Total & 37 & 27 & 60 & 43.8 & 40 & 29.2 & \multirow{2}{*}{0.034} \\
\hline Men & 29 & 33 & 39 & 44.3 & 20 & 22.7 & \\
\hline Women & 8 & 16.3 & 21 & 42.9 & 20 & 40.8 & \\
\hline
\end{tabular}

* p for the chi $i^{2}$ test

Table V. Distribution of the number of completed postgraduate studies in gender groups $(n=137)$.

Source: Own study.

However, Table VI summarises the percentage distribution of the number of completed studies in education groups. The results indicate that the number of completed postgraduate studies is significantly related to the previous education of directors. In the group of persons with non-medical education, $40.7 \%$ of the respondents completed 2 or more postgraduate studies. This is almost seven times greater than for those having a medical education $(6.5 \%)$. Analysing individual categories of education, it can be observed that those who have completed 2 or more postgraduate studies are the people who have engineering $(44.4 \%)$, economic $(42.3 \%)$ or other $(40.0 \%)$ educational qualifications.

The analysis of the data contained in Tables $\mathbf{V}$ and VI also revealed that there is a relatively large group of people who have not completed any postgraduate studies. Almost $40 \%$ of doctors, the highest proportion, were in this group, as were $1 / 3$ of the men. The smallest percentages who had not undertaken postgraduate studies were women, engineers and lawyers - 16\%, 17\% and $18 \%$ respectively.

The most numerous group consists of people who had completed one study, which comprised $44 \%$ of the surveyed population, and the results for women and men in this group are similar.

\begin{tabular}{|c|c|c|c|c|c|c|c|}
\hline & \multicolumn{2}{|c|}{ 0 } & \multicolumn{2}{|c|}{1} & \multicolumn{2}{|c|}{2 or more } & \multirow{2}{*}{$p^{*}$} \\
\hline & $n$ & $\%$ & $n$ & $\%$ & $n$ & $\%$ & \\
\hline \multicolumn{8}{|l|}{ Education } \\
\hline Economic & 7 & 26.9 & 8 & 30.8 & 11 & 42.3 & \multirow{5}{*}{0.014} \\
\hline Engineering & 3 & 16.7 & 7 & 38.9 & 8 & 44.4 & \\
\hline Medical & 18 & 39.1 & 25 & 54.3 & 3 & 6.5 & \\
\hline Legal & 3 & 17.6 & 8 & 47.1 & 6 & 35.3 & \\
\hline Other & 6 & 20.0 & 12 & 40.0 & 12 & 40.0 & \\
\hline \multicolumn{8}{|c|}{ Education (simplified) } \\
\hline Medical & 18 & 39.1 & 25 & 54.3 & 3 & 6.5 & \multirow{2}{*}{$<0.001$} \\
\hline Non-medical & 19 & 20.9 & 35 & 38.5 & 37 & 40.7 & \\
\hline
\end{tabular}

* p for the chi $i^{2}$ test

Table VI. Distribution of the number of completed postgraduate studies in prior educational groups $(n=137)$.

Source: Own study. 


\section{Other factors related to the number of postgraduate studies completed}

Considering the number of completed postgraduate studies, age and the length of employment in the healthcare system/as a hospital director, a statistically significant relationship was observed only for the age of directors. The lower the age of the person, the more postgraduate studies he, or she, had completed $(p=0.017)$. The data illustrating these aspects are shown in Table VII.

The status of a hospital, the establishing entity and the age were not significantly related to the number of completed postgraduate studies (Table VIII).

\begin{tabular}{|l|c|c|c|c|}
\hline & $\begin{array}{c}\mathbf{0} \\
\boldsymbol{n}=\mathbf{3 7}\end{array}$ & $\begin{array}{c}\mathbf{1} \\
\boldsymbol{n}=\mathbf{6 0}\end{array}$ & $\begin{array}{c}\mathbf{2} \text { or more } \\
\boldsymbol{n}=\mathbf{4 0}\end{array}$ & $\boldsymbol{p}^{*}$ \\
\hline Age [years] average $(S D)$ & $57(8)$ & $55(7)$ & $52(8)$ & 0.017 \\
\hline $\begin{array}{l}\text { Length of employment } \\
\text { in healthcare [years] median } \\
(I Q R)\end{array}$ & $22(27)$ & $22(16)$ & $17(12)$ & 0.114 \\
\hline $\begin{array}{l}\text { Length of employment as } \\
\text { a hospital director [years] } \\
\text { median }(I Q R)\end{array}$ & $5(7)$ & $5(11.5)$ & $8(8.5)$ & 0.642 \\
\hline
\end{tabular}

* p for one-way ANOVA or the Kruskal-Wallis test

Table VII. Relationship between the number of completed postgraduate studies and the selected quantity variables $(n=137)$.

Source: Own study.

\begin{tabular}{|c|c|c|c|c|c|c|c|}
\hline & \multicolumn{2}{|c|}{$\mathbf{0}$} & \multicolumn{2}{|c|}{1} & \multicolumn{2}{|c|}{2 or more } & \multirow{2}{*}{$p^{*}$} \\
\hline & $n$ & $\%$ & $n$ & $\%$ & $n$ & $\%$ & \\
\hline \multicolumn{8}{|l|}{ Age } \\
\hline Less than 45 years & 2 & 10.0 & 8 & 40.0 & 10 & 50.0 & \multirow{5}{*}{0.408} \\
\hline $45-50$ years & 8 & 30.8 & 11 & 42.3 & 7 & 26.9 & \\
\hline $51-55$ years & 7 & 24.1 & 12 & 41.4 & 10 & 34.5 & \\
\hline $56-60$ years women and $56-65$ men & 14 & 31.1 & 22 & 48.9 & 9 & 20.0 & \\
\hline More than 61 for women and 66 for men & 6 & 35.3 & 7 & 41.2 & 4 & 23.5 & \\
\hline \multicolumn{8}{|l|}{ Hospital status } \\
\hline Non-public healthcare facility & 9 & 29.0 & 11 & 35.5 & 11 & 35.5 & \multirow{2}{*}{0.492} \\
\hline Independent state healthcare facility & 25 & 24.3 & 49 & 47.6 & 29 & 28.2 & \\
\hline \multicolumn{8}{|l|}{ Establishing authority } \\
\hline County $^{5}$ & 15 & 23.4 & 28 & 43.8 & 21 & 32.8 & \multirow{3}{*}{0.931} \\
\hline Province & 11 & 26.2 & 20 & 47.6 & 11 & 26.2 & \\
\hline $\begin{array}{l}\text { Ministry (Ministry of Health, Ministry } \\
\text { of National Defence, Ministry of Internal } \\
\text { Affairs and Administration) }\end{array}$ & 4 & 36.4 & 4 & 36.4 & 3 & 27.3 & \\
\hline Others ${ }^{6}$ & 4 & 36.4 & 4 & 36.4 & 3 & 27.3 & \\
\hline
\end{tabular}

* p for the chi ${ }^{2}$ test or Newman's exact test

Lack of data: establishing authority $=9$, hospital status $=3$.

Table VIII. Relationship between the number of completed postgraduate studies and the selected quality variables $(n=137)$.

Source: Own study.

\section{Types of studies undertaken by directors and factors related to the completion of postgraduate studies in healthcare management}

The directors completed various postgraduate studies. To conduct the analysis, it was necessary to group study subjects into categories, which are presented in Table IX.

The type of completed postgraduate studies did not have a statistically significant relationship with the analysed quantitative variables (age and employment length) - Table X.

\begin{tabular}{|l|c|}
\hline \multicolumn{1}{|c|}{ Postgraduate study subjects } & [\%] \\
\hline Management in healthcare $^{7}$ & 43 \\
\hline Accounting and finance & 12 \\
\hline Others & 16 \\
\hline Management & 15 \\
\hline Others connected with healthcare & 6 \\
\hline Law & 5 \\
\hline Audit and Control & 3 \\
\hline Total & 100 \\
\hline
\end{tabular}

Table IX. Postgraduate study subjects completed by directors [\%]. Source: Own study. 


\begin{tabular}{|l|c|c|c|}
\hline & $\begin{array}{c}\text { Management } \\
\text { in Healthcare } \\
\boldsymbol{n}=\mathbf{6 7}\end{array}$ & $\begin{array}{c}\text { Others } \\
\boldsymbol{n}=\mathbf{3 3}\end{array}$ & $\boldsymbol{p}^{*}$ \\
\hline Age [years] average $(S D)$ & $53(8)$ & $55(7)$ & 0.181 \\
\hline $\begin{array}{l}\text { The length of employment } \\
\text { in healthcare [years] average } \\
(S D)\end{array}$ & $21(10)$ & $19(12)$ & 0.305 \\
\hline $\begin{array}{l}\text { The length of employment as } \\
\text { hospital director [years] median } \\
(I Q R)\end{array}$ & $8(8)$ & $4(13)$ & 0.139 \\
\hline
\end{tabular}

* p for t test for independent samples and the Mann-Whitney U test + The analysis excluded people who did not complete any postgraduate studies $(n=37)$.

Table X. Relationship between the type of completed postgraduate studies and chosen quantity variables $(n=100 \%)$.

Source: Own study.

\section{Multifactorial analysis}

- Factors related to a larger number of completed postgraduate studies

A larger number of completed postgraduate studies within the group of surveyed directors was significantly associated with them being younger, the possession of non-medical qualifications and a period of work as a hospital director greater than six years, as indicated in Table XI.

\begin{tabular}{|c|c|c|c|}
\hline & B & $95 \% \mathrm{CI}$ & $p^{*}$ \\
\hline Age [years] & -0.025 & $-0.05-0.0002$ & 0.052 \\
\hline $\begin{array}{l}\text { Length of employment } \\
\text { in healthcare [years] }\end{array}$ & -0.006 & $-0.026-0.014$ & 0.540 \\
\hline \multicolumn{4}{|l|}{ Gender } \\
\hline Women & \multicolumn{3}{|c|}{ Ref. } \\
\hline Men & -0.255 & $-0.616-0.105$ & 0.164 \\
\hline \multicolumn{4}{|l|}{ Education } \\
\hline Non-medical & \multicolumn{3}{|c|}{ Ref. } \\
\hline Medical & -0.562 & $-1.01-(-0.12)$ & 0.013 \\
\hline \multicolumn{4}{|c|}{ Length of employment as hospital directort } \\
\hline Less than 6 years & \multicolumn{3}{|c|}{ Ref. } \\
\hline More than 6 years & 0.557 & $0.193-0.920$ & 0.003 \\
\hline \multicolumn{4}{|l|}{ Hospital status } \\
\hline $\begin{array}{l}\text { Independent state healthcare } \\
\text { facility }\end{array}$ & \multicolumn{3}{|c|}{ Ref. } \\
\hline Non-public healthcare facility & 0.002 & $-0.395-0.398$ & 0.994 \\
\hline
\end{tabular}

$p$ - multifactorial linear regression

+ To divide into a dichotomous variable, a median was used.

$B$ - non-standardized linear regression coefficient, 95\% CI-95\% confidence interval.

Table XI. Evaluation of the relationship between the number of completed postgraduate studies and the chosen independent variables with the use of the linear regression analysis $(n=137)$.

Source: Own study.
- Factors related to the completion of postgraduate studies in healthcare management

The logistic regression analysis revealed that the completion of postgraduate studies in healthcare management, compared to the completion of another type of study, is statistically significantly related to: age, employment length as a hospital director and the number of completed postgraduate studies. An increase in age by 1 year reduces the chance of graduating from health management studies by $9 \%$. However, among those who completed 2 or more postgraduate studies, compared to those who completed only 1 postgraduate study, or had worked as a hospital director for more than 6 years, compared to persons who had worked for less than 6 years, the probability of completing studies in health management was 3 times higher (Table XII).

It is worth noting that in the case of doctors, studies in health management constituted $68 \%$ of the studies undertaken, and another $16 \%$ studied management in general. This indicates (total of $84 \%$ of the courses) that the doctors basically were not interested in any other fields of study. The rounded indicators for the non-doctors are $38 \%, 15 \%$ and $52 \%$, respectively.

\begin{tabular}{|c|c|c|c|}
\hline & OR & $95 \% \mathrm{CI}$ & $p^{*}$ \\
\hline Age [years] & 0.91 & $0.85-0.99$ & 0.022 \\
\hline $\begin{array}{l}\text { Length of employment in health- } \\
\text { care [years] }\end{array}$ & 1.03 & $0.97-1.09$ & 0.408 \\
\hline \multicolumn{4}{|l|}{ Gender } \\
\hline Women & \multicolumn{3}{|c|}{ Ref. } \\
\hline Men & 0.87 & $0.33-2.29$ & 0.775 \\
\hline \multicolumn{4}{|l|}{ Education } \\
\hline Non-medical & \multicolumn{3}{|c|}{ Ref. } \\
\hline Medical & 1.60 & $0.43-5.95$ & 0.483 \\
\hline \multicolumn{4}{|c|}{ Length of employment as hospital director } \\
\hline Less than 6 years & \multicolumn{3}{|c|}{ Ref. } \\
\hline More than 6 years & 3.05 & $0.999-9.29$ & 0.050 \\
\hline \multicolumn{4}{|c|}{ Number of completed postgraduate studies } \\
\hline 1 & \multicolumn{3}{|c|}{ Ref. } \\
\hline 2 or more & 3.06 & $1.05-8.96$ & 0.041 \\
\hline \multicolumn{4}{|l|}{ Hospital status } \\
\hline $\begin{array}{l}\text { Independent State Healthcare } \\
\text { Facility }\end{array}$ & \multicolumn{3}{|c|}{ Ref. } \\
\hline Non-public Healthcare Facility & 0.67 & $0.21-2.10$ & 0.491 \\
\hline
\end{tabular}

$* p-$ multifactorial logistic regression (coding of dependent variable: 0 - other postgraduate studies, 1 -Management in Healthcare)

\$ The analysis excluded people who did not complete any postgraduate studies $(n=37)$.

$\uparrow$ To divide into a dichotomous variable, a median was used. OR - odds ratio, $95 \% \mathrm{CI}-95 \%$ confidence interval.

Table XII. Evaluation of the relationship between the type of completed postgraduate studies (others vs Management in Healthcare) and the chosen independent variables with the use of the logistic regression analysis $(N=100 \%)$.

Source: Own study. 


\section{Final remarks}

There are several issues to consider when analysing and interpreting test results.

The respondents were asked to list the studies in which they had graduated, regardless of when it happened. This means that those who had previous professional experience in other industries could list the studies they took while working in those industries. This may be evidenced, for example, by the fact that out of 19 people who declared their graduation in accounting and finance, 10 had an economic education, no doctor undertook this field of studies. Only doctors took up postgraduate studies while working in the healthcare sector, although it is impossible to assess whether they took them up as directors.

Some respondents reported that they had completed not only postgraduate studies, but had also undertaken various types of training courses and specialisations. This applied to all the groups, especially doctors. However, on the basis of the data collected during the research, it is impossible to determine how the question about postgraduate education was interpreted and whether everyone reported their completed specialisations.

The analysis of the data on MBA studies, including MHA, the completion of which was reported by some people, was abandoned. Due to their specificity, e.g. longer study period, the survey did not explicitly ask about this type of study. The analysis of the data relating to specialisations was also abandoned. In this case, the reporting rate was even lower than for MBA studies. It should be noted, however, that a large proportion of medical directors, if not all, wanting to keep the right to practise their profession and work as doctors in the event of resignation or dismissal from the position of director, needed to have some forms of specialisation.

During the work on the paper, information explaining what postgraduate studies for hospital directors were, was also sought from English sources; however, no relevant information to the issue in Poland was found. In the "grey literature" or popular media, advice can be found that while planning for a career as a hospital director, it is worth obtaining a master's degree in healthcare management $[21,22]$. Nevertheless, there is no information about the programmes that would be equivalent to postgraduate studies.

\section{Conclusions}

Although there is not one strong pattern or relationship according to which hospital directors undertake postgraduate studies, there are several phenomena that have been identified by the research. Women more often than men enhance their qualifications in this way, as do non-doctors compared to doctors. In the non-doctor groups, most often people with engineering and "other" education undertook postgraduate studies. Perhaps this derives from an appreciation by those in these groups that their education does not give them sufficient competence to manage hospitals, which is neither medical nor economic nor managerial nor legal. Younger people who have held a directorship for longer than 6 years have studied more frequently.

The greater tendency for women to study, than men, is well documented [23], as is the inverse relationship between age and the willingness to study [24]. It is no different in the healthcare sector. However, the differences between doctors and non-doctors can be interpreted in two ways. The former can develop professionally by performing as doctors (medical specialisations), they may also feel that having a medical education and experience in the healthcare sector, probably including managerial experience, e.g. as head physicians, they have sufficient competence to run hospitals. It is not without significance that this group was dominated by older men with the average age of doctors being statistically significantly higher than for non-doctors, respectively: 57.3, 52.8; $p=0.001$, which would also explain their "doubly" lower tendency to undertake a study.

In addition to the arguments explaining the differences in the undertaking of studies by the various groups, another theory can be put forward. It can be presumed that younger people, when planning their future career, recognised that their studies could help them to subsequently advance that career and allow them to meet the requirements to apply for managerial positions. However, the older people, predominantly doctors, holding consulting positions for a long time did not have to worry about fulfilling those requirements.

In other words, young people "secured" requirements for their future. The above hypotheses should be verified in the course of further research.

When formulating conclusions from the survey, it is worth referring to the results of the literature analysis and the actual lack of articles on the qualifications/ competencies of hospital directors. This would suggest that this matter is not of interest to researchers. The scant information that has been found in the "grey literature" or popular media indicates that other groups, including the representatives of authorities establishing hospitals, do not show an interest in this matter. This may be interpreted as a sign that the type of qualifications and competencies of directors is of no importance to hospital owners. It would appear that they considered that having three-year experience in a "managerial position", without defining what this position has to involve, which means that any managerial position is acceptable, and to have completed postgraduate studies in management subjects is sufficient to apply for a management position of the facility, which is responsible for providing a significant portion of the healthcare services for the inhabitants of a county or province. It is true that? Beata Glinkowska states that employee competencies influence the effective management of an organisation only to a small extent; other elements that have an impact are "practices mainly related to human resource management, job satisfaction and involvement in it" [25]. These, however, are a derivative of the competencies and actions of the person responsible for the entire organisation, in this case the hospital director. 
The presented material does not allow for an analysis referring to which acquired competencies actually help in hospital management and improve the quality of management. However, one can advance the thesis that most hospital directors in Poland are trying to broaden the knowledge that could help them cope with changes in the healthcare system. In any case, they hold a diploma in postgraduate studies, most of which are in management, mainly - in healthcare management.

\section{Notes}

${ }^{1}$ To simplify the language, the term "studies" will be understood as postgraduate studies, in accordance with the provisions of the Act of 27 July 2005 - Law on Higher Education (No.164, item 1365 with later amendments) unless otherwise specified in the paper. The reference to this act (non-binding) results from the fact that the research was carried out at the time when the act was in force.

${ }^{2}$ Including a city with the rights of a county.

${ }^{3}$ This category, due to the small number of units, comprises those owned by a university or non-public institution.

${ }^{4}$ These people also declared graduation from MBA and/or specialisation.

${ }^{5}$ Including a city with the rights of a county.

${ }^{6}$ This category, due to a small number of units, comprises those owned by a university or non-public institution.

${ }^{7}$ These studies had various names - Management in Healthcare, Management of Healthcare Facilities, etc.

\section{References}

1. Bratnicki M., Kompetencje przedsiębiorstwa od określenia kompetencji do zbudowania strategii, Placet, Warszawa 2000: 33.

2. Pocztowski A., Zarzadzanie zasobami ludzkimi. Strategieprocesy-metody, PWE, Warszawa 2003: 153.

3. Janowska Z., Zarządzanie zasobami ludzkimi. Wyzwania XXI wieku, PWE, Warszawa 2001: 90.

4. Sajkiewicz A., Jakość zasobów pracy. Kultura, kompetencje, konkurencyjność, Poltext, Warszawa 2004: 17-18.

5. Słownik języka polskiego, PWN; https://sjp.pwn.pl/sjp/ kompetencja;2564077 (accessed: 25.03.2019).

6. Słownik języka polskiego; https://sjp.pl/kompetencja (accessed: 25.03.2019).

7. Instytut Języka Polskiego Polskiej Akademii Nauk, Wielki słownik języka polskiego; https://wsjp.pl/index.php?id hasla $=6956 \& i d \_z n a c z e n i a=4324342 \& 1=7$ (accessed: 25.03.2019).

8. Ustawa z dnia 6 lutego 1997 roku o powszechnym ubezpieczeniu zdrowotnym (Dz.U. $1997 \mathrm{Nr} 28$ poz. 153).

9. Ustawa z dnia 23 marca 2017 roku o zmianie ustawy o świadczeniach opieki zdrowotnej finansowanych ze środków publicznych (Dz.U. 2017 poz. 844).

10. Naczelna Izba Pielęgniarek i Położnych, Liczba pielęgniarek $i$ położnych wg przedziałów wiekowych na podstawie daty urodzenia, 2017.02.06; https://nipip.pl/ liczba-pielegniarek-poloznych-wg-przedzialow-wiekowych-podstawie-daty-urodzenia/ (accessed: 14.05.2018).

11. Libura M., Borek E., Maciorowska K., Turkiewicz J., Sitek A., Lekarze i pacjenci $w$ Polsce - model relacji $w$ gabinecie lekarskim AD 2016. Raport z badania opinii lekarzy i pacjentów, Fundacja "My Pacjenci"; https://mypacjenci. org/wp-content/uploads/2018/08/Empowerment_RAPORT.pdf (accessed: 11.05.2018).

12. GUS, Mały Rocznik Statystyczny Polski 2018, Warszawa 2018: 221.

13. Ustawa z dnia 27 lipca 2005 roku - Prawo o szkolnictwie wyższym (Dz.U. Nr 164 poz. 1365 z późn. zm.).

14. Bakonyi J., Studia podyplomowe, szkolenia i kursy jako równoległe formy podnoszenia kwalifikacji, "Zeszyty Naukowe Wyższej Szkoły Humanitas. Zarządzanie” 2013; 2: 93.

15. Central Statistical Office, The Statistical Yearbook of the Republic of Poland 2017, Warsaw 2018: 361.

16. Central Statistical Office, The Statistical Yearbook of the Republic of Poland 2001, Warsaw 2002: 254.

17. Kautsch M., Dela R., Changes in hospital CEO profiles in Poland - Professionalisation of management?, "Int. J. Health Plann. Mgmt." 2019;1-13; https://doi. org/10.1002/hpm.2788.

18. Wójcik M., Profil zawodowy prezesa spótki prowadzacej działalność leczniczą; http://www.infozdrowie.org/ attachments/swiadczeniodawca2013/pdf/4-wojcik.pdf (accessed: 11.03.2014), quote for: Domagała A., Wyksztatcona kadra menedżerska jako warunek skutecznego zarzadzania jednostkami opieki zdrowotnej, "Zeszyty Naukowe Ochrony Zdrowia. Zdrowie Publiczne i Zarządzanie" 2014; 12 (2): 144-152, doi:10.4467/20842627 OZ.14.016.3108.

19. Kautsch M., Sobieralska S., Kto zarządza polskimi szpitalami? "Przedsiębiorczość i Zarządzanie" 2013; XIV (10): 229-240.

20. Ustawa z dnia 15 kwietnia 2011 roku o działalności leczniczej (Dz. U. $2011 \mathrm{Nr} 112$ poz. 654).

21. How to Become a Healthcare Administrator; https://www. learnhowtobecome.org/healthcare-administration/ (accessed: 25.03.2019).

22. Healthcare Management Degree Guide; https://www. healthcare-management-degree.net/faq/what-are-the-major-responsibilities-of-a-health-care-chief-executive-officer/ (accessed: 25.03.2019).

23. GUS, Kobiety i mężczyźni na rynku pracy 2018, Warszawa 2018; https://stat.gov.pl/obszary-tematyczne/rynek-pracy/opracowania/kobiety-i-mezczyzni-na-rynku-pracy-2018,1,7.html (accessed: 12.04.2019).

24. Boni M., Ksztatcenie dorostych: czy chcemy się ksztatcić?, in: U. Sztanderska, E. Drogosz-Zabłocka, B. Minkiewicz (eds.), Edukacja dla pracy. Raport o rozwoju społecznym Polska 2007, Program Narodów Zjednoczonych ds. Rozwoju, Warszawa 2007: 66.

25. Glinkowska B., Kompetencje pracownika a efektywność organizacji, in: T. Dudycz, G. Osbert-Pociecha, B. Brycz (eds.), Efektywność - konceptualizacja i uwarunkowania, Prace Naukowe Uniwersytetu Ekonomicznego we Wrocławiu, 262, Wydawnictwo Uniwersytetu Ekonomicznego we Wrocławiu, Wrocław 2012: 130. 